\title{
Article
}

\section{A Bibliometric Review of Sustainable Product Design}

\author{
Pingfei Jiang ${ }^{1, *(\mathbb{D}}$, Elena Dieckmann ${ }^{2}$, Ji Han $^{3}\left(\mathbb{D}\right.$ and Peter R. N. Childs ${ }^{2} \mathbb{( D}$ \\ 1 School of Engineering and the Environment, Kingston University London, London SW15 3DW, UK \\ 2 Dyson School of Design Engineering, Imperial College London, London SW7 2DB, UK; \\ Elena.dieckmann13@imperial.ac.uk (E.D.); P.childs@imperial.ac.uk (P.R.N.C.) \\ 3 School of Engineering, University of Liverpool, Liverpool L69 3BX, UK; Ji.han@liverpool.ac.uk \\ * Correspondence: P.Jiang@kingston.ac.uk
}

check for

updates

Citation: Jiang, P.; Dieckmann, E.; Han, J.; Childs, P.R.N. A Bibliometric Review of Sustainable Product Design. Energies 2021, 14, 6867. https://doi.org/10.3390/en14216867

Academic Editor: Ben McLellan

Received: 30 September 2021

Accepted: 18 October 2021

Published: 20 October 2021

Publisher's Note: MDPI stays neutral with regard to jurisdictional claims in published maps and institutional affiliations.

Copyright: (c) 2021 by the authors. Licensee MDPI, Basel, Switzerland. This article is an open access article distributed under the terms and conditions of the Creative Commons Attribution (CC BY) license (https:// creativecommons.org/licenses/by/ $4.0 /)$.

\begin{abstract}
Consideration of sustainability in product development is becoming increasingly important and encompasses many aspects of product design. In this study, a bibliometric review of recent sustainable product design publications using Web of Science and VOSViewer is carried out. The review indicates that the majority of publications concerning sustainable product design is oriented towards environmental science-led subject areas and production-led journals. Analysis of author keyword co-occurrences reveals that circular economy, life cycle assessment, sustainable management, and optimization are the most popular topics in sustainable product design research. The analysis also reveals that the researchers fail to link sustainability research to activities in product design, which leads to the lack of access to relevant research that can make products more sustainable. Building on the findings, the authors propose four future research directions that aim to guide researchers to better correlate sustainability with product design, namely: sustainability interpretation, integration, assessment and validation, and improvement.
\end{abstract}

Keywords: sustainability; product; design; literature; review; environment

\section{Introduction}

The academic discourse on sustainable product design has been thriving since Victor Papanek's manifesto in 1985 [1]. However, a recent report by a group of data scientists of the Circular Economy states that only $8.6 \%$ of the world is circular [2]. Products account for a vast amount of resource depletion, and even though research addresses this issue through the development of sustainability tools for product design, the effect on design practice is unnoticeable. The intersection of product design methodology and sustainability is of interest for many research groups globally, which is reflected in an extensive landscape of models and frameworks with a specific terminology. Examples include end-of-life (EoL), which defines instruments for recovery strategies. The concept of closed-loop systems and circular design gained popularity through a charitable initiative (Ellen McArthur Foundation). Through the concept of circular economy, closed-loop material-flows are meant to guide material selection in product design stages and assembly and disassembly mechanisms [3]. Product design has therefore, in recent years, experienced a paradigm shift to proactively design a product lifecycle, rather than a product only (Design for Life-Cycle), utilizing qualitative and quantitative sustainability indicators [4]. Another popular philosophy is Cradle-to-Cradle design, which suggests a metaphorically nutrient-based perpetual flow of biological and technical metabolisms [5]. In addition to these well-established thought models, several researchers have proposed assessment systems, aiming to minimize the impact of products by enhancing decision making during the design process [6-8]. Mostly, this is achieved by environmental profiling of the bill of materials and assessing production methods. Han et al. formulated a practical, metric-based system, covering the topics of material, production, use, and end of life to support designers in producing sustainable design concepts [9]. Rodrigues et al. performed a comprehensive literature review 
and extracted key performance indicators (KPIs) that effectively inform on sustainability performance in product development during the design process. The authors recognized that the identified KPIs are mostly related to high-level product strategy rather than the actual design process [10]. Some researchers state that circular design has little emphasis on the behavioral aspect of product use, which impacts environmental performance through the specification of use efficiency, frequency, and consumption patterns [11].

Even though there are many tools available to implement sustainable product design in theory, it appears that those systems are not utilized by designers. Instead, product sustainability evaluation is often conducted only through life-cycle assessment (LCA) [12-14] and quality function deployment (QFD) [15-17] when the main features and functionalities of the product have been irreversibly decided. Although plenty of methodological tools are published, there is an apparent gap between design intent and design reality. In the context of sustainability, design has a pivotal role in defining a product, system, or service, its make-up, and how it is intended to be used. It is therefore worth investigating to what extent design affords consideration of sustainability. Some design approaches make explicit reference to sustainability, while others do so implicitly. Whether consideration is given implicitly or explicitly, in the context of sustainability, it is the extent to which the process delivers a result that provides benign outcomes that is important. This paper investigates the correlation between the research of product design and sustainability using bibliometric data visualization. Furthermore, this study quantitatively analyses key terminology utilized in both product design and sustainability research and aims to identify interlinking theme clusters. This demonstrates how researchers address sustainability in product design. With hundreds of new products launched every day globally, it is important to understand the current role of sustainability with product development and its function in the design process.

\section{Background}

\subsection{Sustainability}

Sustainability is considered a significant focal topic by both researchers and the public. It is often discussed in areas such as environmental sciences, energy, engineering, business, management, economics, and design. Researchers from these areas have provided many definitions of sustainability at various levels of scope and complexity, such as 'the ability to continue into the future' [18], 'the use of the vital functions (possible uses) of our biophysical surroundings in such a way that they remain indefinitely available' [19], 'the possibility that human and other forms of life will flourish on the planet forever' [20], 'economic development that creates value for customers, shareholders, stakeholders, and society by designing and operating the business in a way that aligns with ecosystems, in service of human prosperity, today and in the future' [21], and 'environmental quality and well-being' [22]. Although sustainability is an inherently complex and vague concept that is difficult to define, it is commonly accepted as 'development that meets the needs of the present without compromising the ability of future generations to meet their own needs' [23].

Economic, social, and environmental are the three dimensions of sustainability, which are often presented in a Venn diagram, in which sustainability is at the confluence of three interconnected circles representing the dimensions. This is known as the three-pillar conception of sustainability [24], which shows that responsible development requires considering profits, humans, and the planet [25]. The three pillars have been criticized by several researchers, for example, Littig and Griessler [26] suggested that there is a lack of understanding of how the three dimensions are related to one another and how the dimensions should be measured, Miller [27] indicated that the three pillars classification might have limited users focusing on compromising between the three components, and Eslami et al. [28] argued that the categorization for the dimensions is too broad and that more delineation is needed for specific sustainability issues. However, the three pillars of sustainability have initiated a great number of local, regional, and global efforts to 
achieve sustainability by addressing societal challenges and mitigating environmental damage, along with human development [29].

\subsection{Sustainability in Product Design}

Design involves the transformation of an existing state into a preferred state. In the context of product design, it can refer to the necessary activity that provides a product to meet a market need [30]. It is the key stage at which $80 \%$ of sustainability impacts are determined for a product [6], while addressing sustainability issues at later stages, such as manufacture and use, is challenging and costly [31,32]. There are many approaches to design, and each designer may use or develop an approach that works for their context. Some companies have frameworks that employees are expected to work within, which have been found to deliver work to defined standards. For example, green design, eco-design, emotionally durable design, and cradle-to-cradle design have emerged since the 1990s for supporting sustainability in product design $[11,33]$. The environmental dimension is considered the primary focus of the three in product design [34], where sustainable design is mainly aimed at reducing a product's environmental footprints during its life cycle [35]. Nevertheless, sustainability in product design has progressively expanded from product level to socio-technical system level, which embodies design for product-service systems and social innovation [11].

In industry, a dominant process for undertaking a product design action is by means of a project. Projects can be characterized as well-defined, defined, and undefined. Dominant approaches, are commonly adopted for well-defined projects, include waterfall. For defined projects, traditional project management approaches and, for un-defined projects agile management approaches are sometimes used. Design methods, applicable in these projects, can be classified into the following categories: procedural, deterministic, analytical, abstract, and design thinking, and examples of each are provided in Figure 1. Each approach has been subject to extensive study, and hybrids are also possible. A detailed analysis of a given design approach is possible, for example, investigating how the approach addresses different aspects of sustainability. Demonstration of the effectiveness could be made via a series of case studies addressing different applications. However, in the context of this paper, such an undertaking would be a massive research program and is instead suggested as an activity for future work and the wider research community. Here, one approach, represented by the blended design model [36], is considered as this combines principles of project management and procedural design, with recognizable phases from industrial practice, as shown in Figure 2.

Project Characteristics

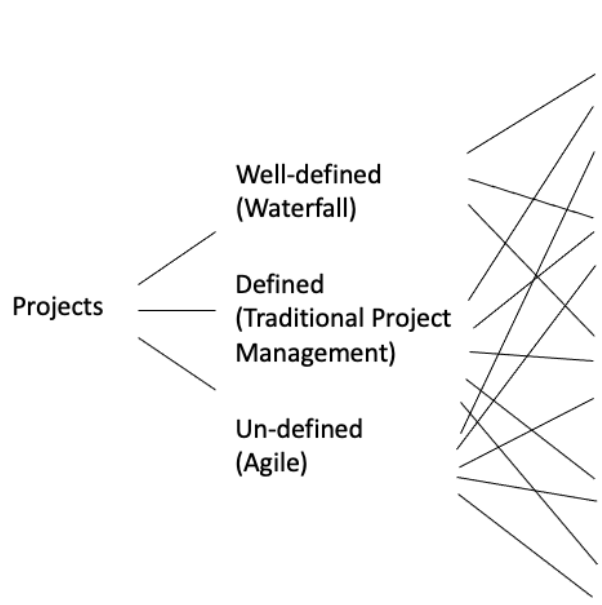

Design Model

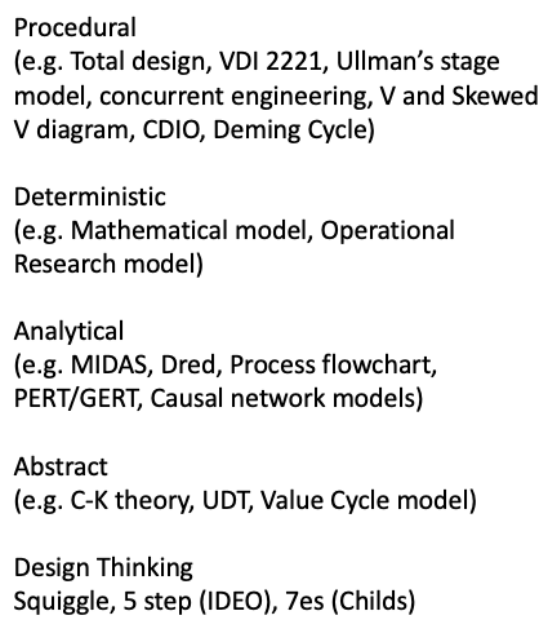

Figure 1. Classification of design methods. 


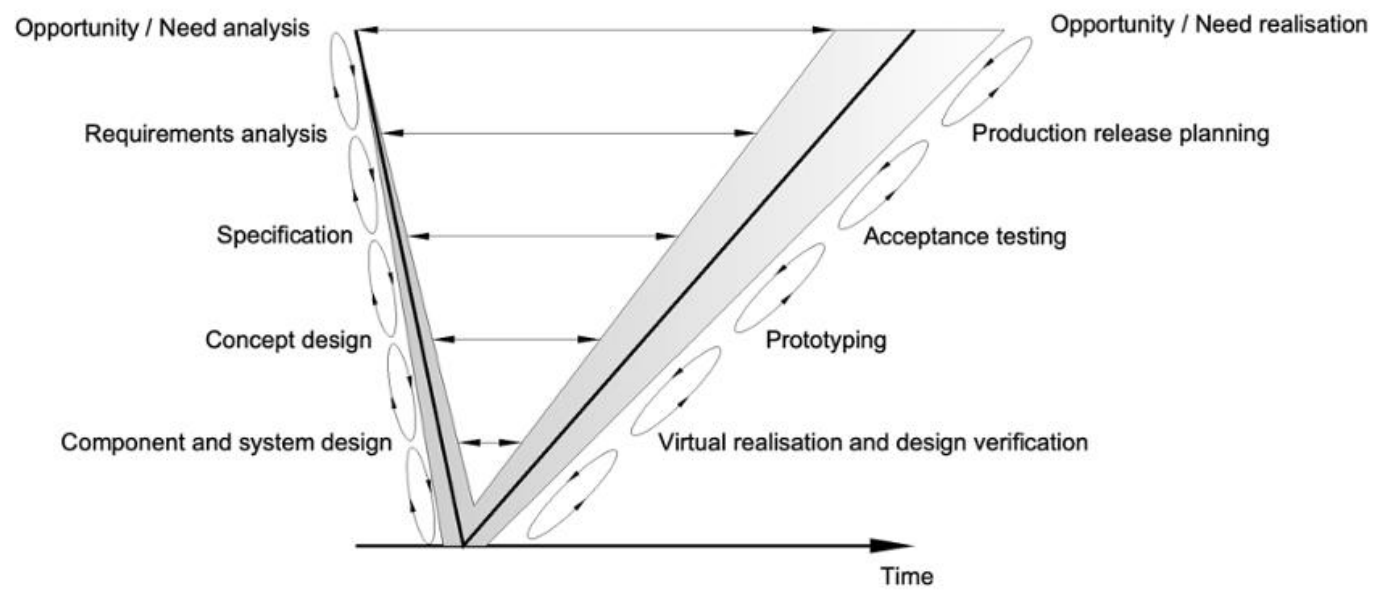

Figure 2. Blended design process, i.e., the skewed V-diagram [36].

The blended design process [36] comprises phases of opportunity analysis, requirement analysis, specification, concept design, system analysis, prototyping, testing, production planning, and opportunity realization. The phases follow an adapted timeline from the classic V model [37], but this is skewed to take account of the increased resources associated with some activities. Each phase of the blended design process is connected to a corresponding phase to indicate and prompt consideration of the relevant aspects, be it from the initial design activity or detailed planning. The phases are also connected to adjacent phases to prompt and indicate iteration with flows back and forth of information and revisiting of ideas and decisions as new information emerges. Typical design processes do not explicitly define sustainability as a principal activity or function in different stages. Instead, the classifications used with the model description are broad and generic. This could be viewed as a benefit or a risk, depending on whether the individual designer or company concerned is willing or able to apply considerations of sustainability and the associated tools and significant resources available. For example, in requirements analysis, the need for a product, service, or system to perform to a prescribed level of sustainability could be recognized and addressed. In specifications, these levels can then be qualified and quantified as appropriate, for example, ensuring compliance with relevant national and international standards. In conceptual design, ideas can be judged against whether they comply with various sustainability measures, defined and in testing, which is the corresponding phase with specification.

The above discourse indicates that a design model that typifies procedural design can be readily followed to address sustainability issues and considerations at each phase. However, it is also clear that the attention given to a particular set of considerations depends on the judgement and experience of the designer. It is possible that a design team that follows such a process could omit sustainability concerns. High-level strategic frameworks often fail to provide details associated with each phase of a design process, where bespoke checklists are required, depending on the application. These checklists and procedures invariably explicitly state requirements to adhere to sustainability principles, albeit often driven by requirements to adhere to national and international standards. There seems to be a gap between sustainability and design phases in both design research and practice, where sustainability is often considered separately from design phases. Therefore, a review on sustainability consideration in product design is needed, particularly in relation to those procedural design phases, to raise a clearer awareness to researchers and practitioners about the importance of integrating sustainability considered with design phases. In the next section, a series of bibliometric analysis are performed to obtain insight into recent literature on sustainable product design. 


\section{Bibliometric Analysis}

An academic publication contains several sections, including author keywords, which are commonly used in article indexing and abstracting [38]. Author keywords in an academic publication refer to a set of terms defined by the authors and aim to label the topics and subtopics of the article [39]. Using appropriate author keywords, articles can be indexed more easily and accurately, meaning the article will be exposed to a wider range of audiences [40]. Author keywords normally contain 3-7 individual phrases, so they are easier to extract and analyze systematically compared to a title or abstract. As a result, author keywords were used and analyzed in this review to represent the topics covered in an article. In other words, in this article, an overview of how researchers align their articles by using a group of terms that best describe their work is analyzed.

An initial keyword, "sustainable product design", was used to reflect the core topic of this review. The research engine Web of Science (WoS) was used instead of Scopus, due to update cycles [41]. The search was focused on English language records. The search field of WoS was set to include all records, covering all indexable fields, with a temporal range from 2018-01-01 to 2021-08-31. The search returned 7395 publications, with their subject areas categorized by WoS, as shown in Table 1, according to the data mining analysis tool embedded within [42]. It is worth noting that one article can have more than one subject area. From the table, approximately $59 \%$ of the publications are categorized in areas related to sustainable and environmental technologies, comprising green sustainable science technology $(25.9 \%)$, environmental sciences $(21.8 \%)$, and engineering environmental $(10.9 \%)$. Each subject area that can implicitly relate to design processes, e.g., management, manufacturing, and industrial engineering, takes up less than $6 \%$ of the results. This indicates that sustainability is overlooked in product design processes, even though "sustainable product design" was used as the search term.

Table 1. Summary of the WoS search results using "sustainable product design" and their subject areas.

\begin{tabular}{ccc}
\hline Subject Areas & $\begin{array}{c}\text { Number of } \\
\text { Publications }\end{array}$ & \% of the Results \\
\hline Green Sustainable Science Technology & 1922 & 25.991 \\
Environmental Sciences & 1619 & 21.893 \\
Engineering Environmental & 810 & 10.953 \\
Engineering Chemical & 691 & 9.344 \\
Environmental Studies & 647 & 8.749 \\
Chemistry Multidisciplinary & 640 & 8.654 \\
Energy Fuels & 612 & 8.276 \\
Materials Science Multidisciplinary & 495 & 6.694 \\
Management & 443 & 5.991 \\
Engineering Manufacturing & 354 & 4.787 \\
Business & 347 & 4.692 \\
Food Science Technology & 304 & 4.111 \\
Engineering Industrial & 281 & 3.800 \\
Chemistry Physical & 261 & 3.529 \\
Biotechnology Applied Microbiology & 198 & 2.677 \\
Engineering Multidisciplinary & 195 & 2.637 \\
Physics Multidisciplinary & 189 & 2.556 \\
Multidisciplinary Sciences & 188 & 2.542 \\
Engineering Civil & 178 & 2.407 \\
Computer Science Interdisciplinary Applications & 178 & 2.407 \\
Physics Applied & 172 & 2.326 \\
Engions & 154 & 2.082 \\
Eonstruction Building Technology & 139 & 1.880 \\
Economics & 138 & 1.866 \\
\hline
\end{tabular}

When retrieving the results, WoS provides by default results sorted by relevance, based on a ranking system that considers how many of the search terms are found in 
each record. The results can also be sorted by citations that represent the number of citations for each article. When sorted by Citations, articles retrieved tend to be much more domain-specific, which could potentially provide biased results, hence only Relevance was considered in the analysis. Journal titles for the 7395 results were analyzed, and the top 15 journals are presented in Table 2 together with the number of publications identified. The Journals of Cleaner Production and Sustainability dominates the results, with nearly 900 publications, occupying $23 \%$ and $22 \%$ of the results, respectively. In third place is $A C S$ Sustainable Chemistry and Engineering with 234 articles (12\%). It is obvious that researchers correlate sustainability closely with production, which is reflected through the number of articles published in the Journal of Cleaner Production and other production-related journals shown on the list, such as International Journal of Productivity and Performance Management, Procedia Manufacturing, and Procedia CIRP. The production stage has a direct impact on sustainability in terms of emissions, energy consumption, and wastage, but most of these negative impacts are determined in the design stages [43]. Therefore, results from Table 2 indicate that there is a missing correlation between design phrases and sustainability, reflected on the main journal articles published.

Table 2. The main journals published in using "sustainable product design".

\begin{tabular}{cc}
\hline Journal Title & Number of Publications \\
\hline Journal Cleaner Production & 458 \\
Sustainability & 440 \\
ACS Sustainable Chemistry and Engineering & 234 \\
Resources, Conservation and Recycling & 61 \\
International Journal of Productivity and Performance Management & 58 \\
Renewable E Sustainable Energy Reviews & 51 \\
British Food Journal & 48 \\
Green Chemistry & 47 \\
Procedia Manufacturing & 46 \\
Procedia CIRP & 44 \\
Energies & 39 \\
PLoS ONE & 39 \\
Applied Sciences & 34 \\
Sustainable Production and Consumption & 32 \\
International Journal of Sustainable Engineering & 31 \\
\hline
\end{tabular}

Co-occurrence analysis of author keywords for the retrieved results was carried out and visualized using VOSViewer [44], as shown in Figure 3. The size of the label reflects the number of occurrences. The distance between labels refers to their relatedness regarding co-occurrence; in other words, the closer the two labels are, the more likely they are to appear together in an article. The network map suggests six research focuses of sustainable product design, including circular economy (left green cluster), life cycle assessment (central cyan cluster), biomass (right red cluster), optimization (bottom yellow cluster), waste management (top right purple cluster), and quality and consumption management (top blue cluster).

On the far left of the network map, design terms can be identified, e.g., product development, product design, and eco-design. Based on their position, node size, and links with other nodes, it can be inferred that the correlation between design phrases with sustainability is overlooked by most research studies. The majority of research effort has been on either business model and thinking, such as circular economy, or specific topics and techniques, such as optimization and life cycle assessment. 


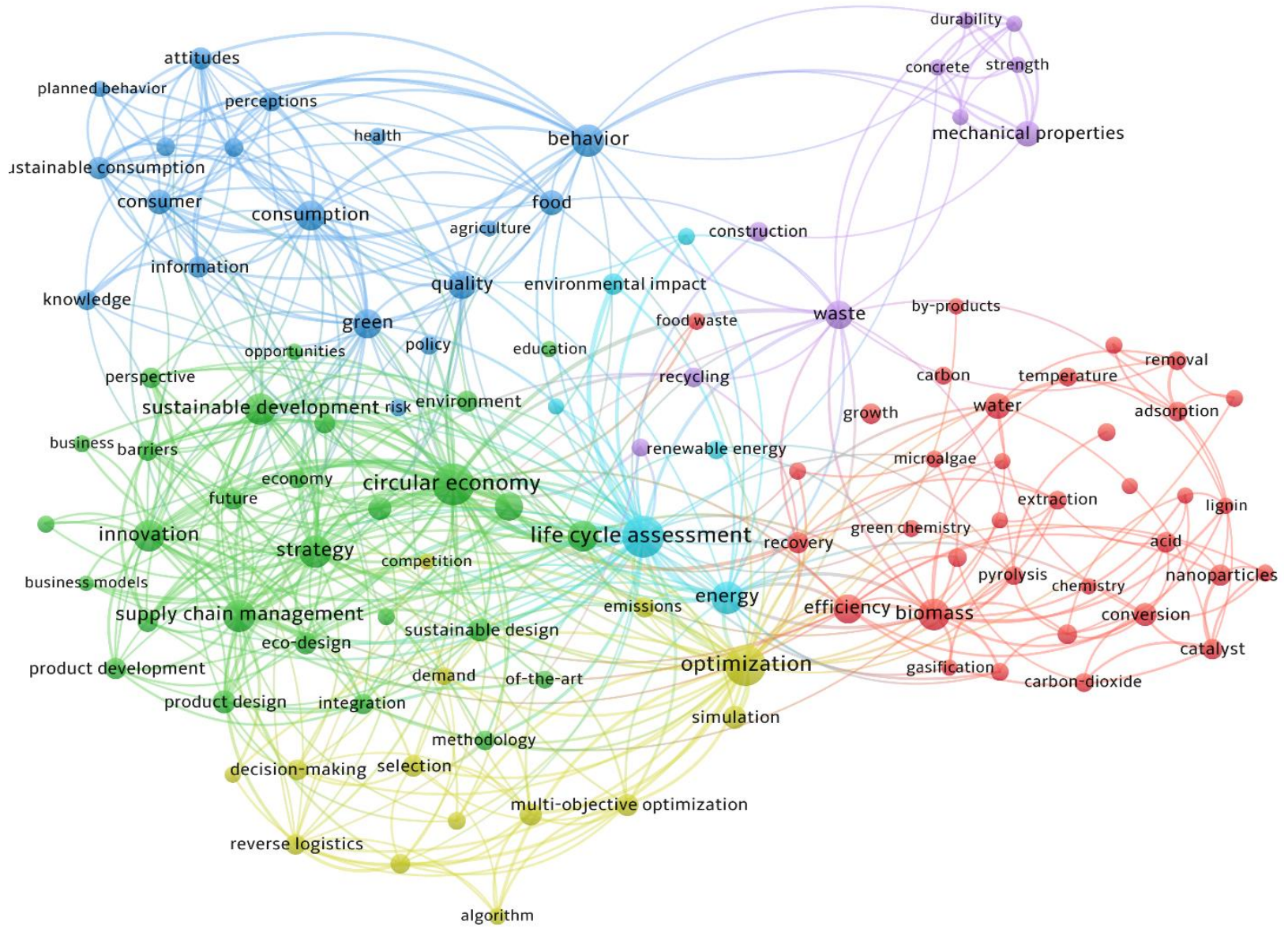

Figure 3. Network map with publications' author keywords co-occurring 50 times or more.

While the focus of this review article is on "sustainability product design", it is necessary to capture all publications related to this topic. As a result, the search scope was broadened using an improved set of search terms, by ranking the author keywords according to their number of occurrences for the first 100 publications within the 7395 results. For all records, the keywords were prepared and consolidated for plurals, spelling, and abbreviations. This provided a list of author keywords, with their number of occurrences indicated in brackets: "sustainable design" (25), "sustainability" (21), "product design" (14), "sustainable product design" (11), and "circular economy" (10). These five terms were used to compose new search queries in WoS.

This time the search field was set to Topic, covering title, author keywords, and abstract. When performing a WoS search using multiple terms, the search criteria can be AND or OR. The former means the results must contain all the terms specified, whilst the latter means the results only need to have at least one of the terms. In other words, when the AND search criterion is used, the results retrieved are likely to be relevant to the search terms but much lower in number. When the OR search criterion is used, many more results are expected with diverse focuses, addressing one or more of the search terms. For example, an initial search using OR between the new five keywords returned more than 250k results even with the date range set to be from 2018 to 2021, compared to the 7395 results previously obtained. To better correlate the search results with product design processes, the skewed V-diagram (see Figure 2) was used as a filter. This was achieved by using the generic terms, describing the key design phrases, i.e., the left half of the diagram, as an additional set of search terms to be used in combination with the five keywords identified in the previous section. Table 3 shows the results of five searches, corresponding to the five key design phrases presented in the skewed V-diagram. A search query can be understood as: obtain results of title, abstract, or author keywords, which contain a 
combination of terms from the two brackets. For example, the first query asks WoS to provide all publications from 2018 to 2021, whose title/abstract/keywords contains either "opportunity" or "need analysis", plus either "sustainable design" or "sustainability" or "product design" or "sustainable product design" or "circular economy". The subject areas analysis carried out by WoS is also included in the Table 3. The first search returned the highest number of results: 24,226 . This is due to the generic descriptions used, such as "opportunity", "need", and "analysis". When the search query contains more domainspecific terms, such as "requirement", "specification", and "component", substantially less results were obtained.

Table 3. Summary of the WoS-search results, corresponding with five key design terms from the skewed V-diagram.

\begin{tabular}{|c|c|c|c|}
\hline Search Query & Number of Results & Subject Areas (Top 5) & Number of Results \\
\hline $\begin{array}{l}\text { (Opportunity OR Need analysis) AND } \\
\text { (sustainable design OR sustainability } \\
\text { OR product design OR sustainable } \\
\text { product design OR circular economy) }\end{array}$ & 24226 & $\begin{array}{c}\text { Environmental Sciences } \\
\text { Green Sustainable Science Technology } \\
\text { Environmental Studies } \\
\text { Management } \\
\text { Engineering Environmental }\end{array}$ & $\begin{array}{l}5418 \\
4452 \\
3319 \\
1690 \\
1609\end{array}$ \\
\hline $\begin{array}{l}\text { (Requirements analysis) AND } \\
\text { (sustainable design OR sustainability } \\
\text { OR product design OR sustainable } \\
\text { product design OR circular economy) }\end{array}$ & 3765 & $\begin{array}{c}\text { Environmental Sciences } \\
\text { Green Sustainable Science Technology } \\
\text { Environmental Studies } \\
\text { Engineering Environmental } \\
\text { Energy Fuels }\end{array}$ & $\begin{array}{l}715 \\
605 \\
331 \\
289 \\
272\end{array}$ \\
\hline $\begin{array}{c}\text { (Specification) AND (sustainable design } \\
\text { OR sustainability OR product design } \\
\text { OR sustainable product design OR } \\
\text { circular economy) }\end{array}$ & 1831 & $\begin{array}{c}\text { Environmental Sciences } \\
\text { Engineering Electrical Electronic } \\
\text { Green Sustainable Science Technology } \\
\text { Engineering Manufacturing } \\
\text { Materials Science Multidisciplinary }\end{array}$ & $\begin{array}{l}172 \\
168 \\
166 \\
159 \\
141\end{array}$ \\
\hline $\begin{array}{l}\text { (Concept design) AND (sustainable } \\
\text { design OR sustainability OR product } \\
\text { design OR sustainable product design } \\
\text { OR circular economy) }\end{array}$ & 9228 & $\begin{array}{c}\text { Green Sustainable Science Technology } \\
\text { Environmental Sciences } \\
\text { Environmental Studies } \\
\text { Management } \\
\text { Engineering Manufacturing }\end{array}$ & $\begin{array}{l}1169 \\
1142 \\
724 \\
693 \\
540\end{array}$ \\
\hline $\begin{array}{l}\text { (Component and system design) AND } \\
\text { (sustainable design OR sustainability } \\
\text { OR product design OR sustainable } \\
\text { product design OR circular economy) }\end{array}$ & 4184 & $\begin{array}{c}\text { Environmental Sciences } \\
\text { Green Sustainable Science Technology } \\
\text { Engineering Electrical Electronic } \\
\text { Energy Fuels } \\
\text { Engineering Manufacturing }\end{array}$ & $\begin{array}{l}424 \\
422 \\
404 \\
401 \\
318\end{array}$ \\
\hline
\end{tabular}

Figure 4 summarizes the subject areas covered by the WoS search results, presented in a ranked order. Similar to the results obtained in Table 1, approximately $73 \%$ of the publications were in the area of green sustainable science technology (30\%), environmental sciences $(26 \%)$, and engineering environmental $(17 \%)$, which have no apparent correlation with product design processes. Management came fourth, but with substantively fewer publications compared to the first three. When analyzing the scope of the main journals that these articles are published in (see Table 4), Sustainability and Journal of Cleaner Production predominated the results, taking $45 \%$ and $33 \%$ of all results, respectively. It can be seen that manufacturing and production are popular topics related to sustainability, with journals such as Sustainable Production and Consumption, International Journal of Advanced Manufacturing Technology, and International Journal of Production Research, but again, no journals that centered around design were identified. This suggests that, when researchers talk about sustainability in design, they tend to focus more on production and manufacturing. 


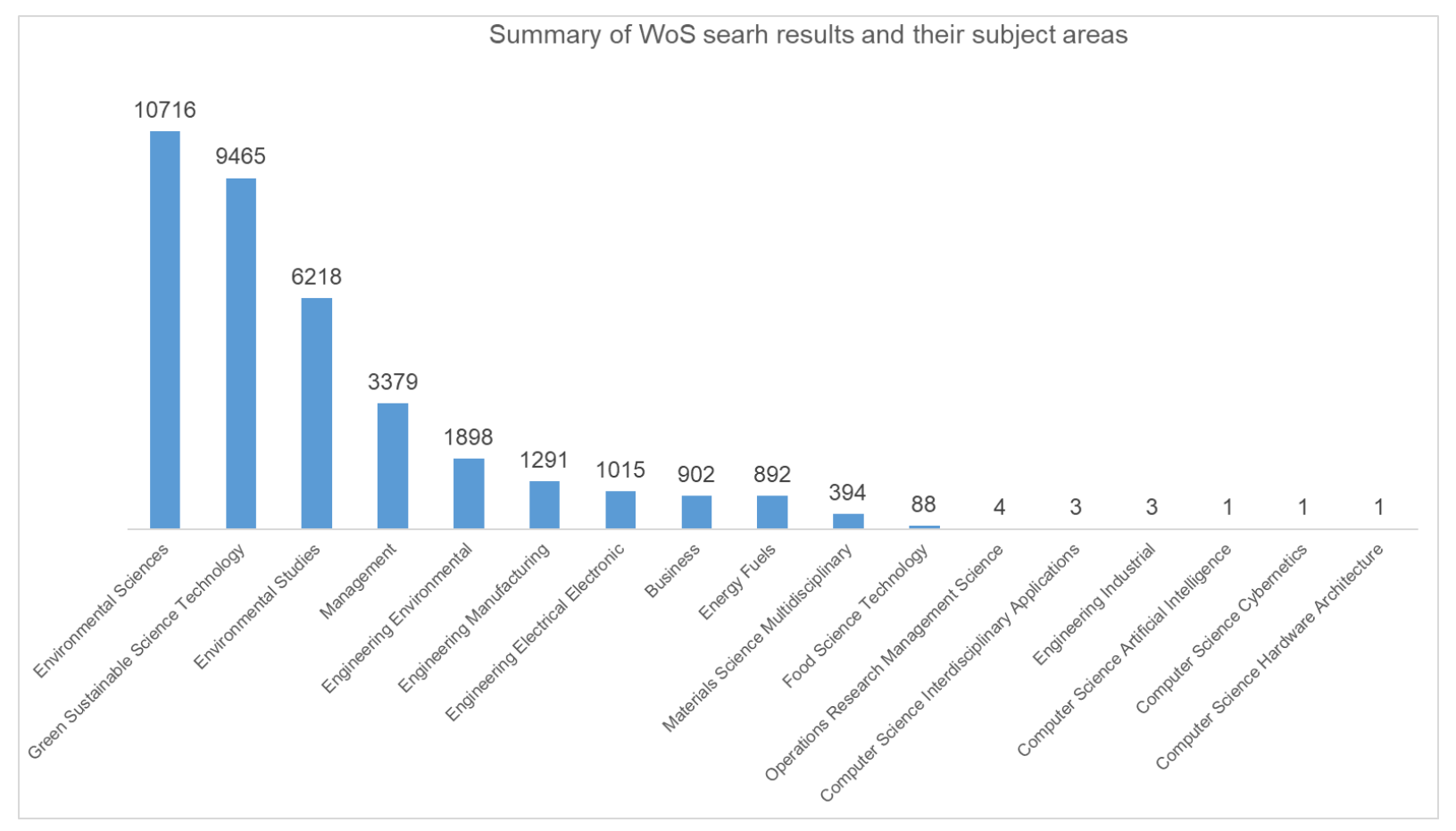

Figure 4. Summary of the search and subject areas covered.

Table 4. The main journals published in combining the five searches. Top 1000 results were used.

\begin{tabular}{cc}
\hline Journal Title & Number of Publications \\
\hline Sustainability & 423 \\
Journal Of Cleaner Production & 309 \\
Resources Conservation and Recycling & 66 \\
International Journal of Advanced Manufacturing Technology & 28 \\
Sustainable Production and Consumption & 25 \\
International Journal of Production Research & 23 \\
Business Strategy and The Environment & 14 \\
Applied Sciences & 13 \\
Energies & 11 \\
Industrial and Engineering Chemistry Research & 11 \\
Journal of Industrial Ecology & 11 \\
Journal of Intelligent Manufacturing & 10 \\
\hline
\end{tabular}

Another co-occurrence analysis of author keywords for the first 1000 results obtained, sorted by Relevance, in the five searches, was carried out and visualized, together using VOSviewer, presented in Figure 5. The analysis suggests that popular research topics of sustainable product design, in a broader context, by utilizing five searches, are in the following areas:

1. Circular economy and life cycle assessment (top left blue cluster).

2. Sustainable development and management (central yellow cluster).

3. Product design and optimization (right red cluster).

4. Business analysis and innovation (bottom left green cluster).

5. Supply chain and logistics management (bottom purple cluster).

From the analysis, it was found that circular economy is the most popular author keyword, indicated by the largest node in the map, followed by management, life cycle assessment, and optimization. Research that addresses circular economy is closely related to sustainability management and business analysis, whilst life cycle assessment is often associated with product design and optimization. Terms that are familiar to designers, such as conceptual design, quality function deployment, and decision-making, belong to the third cluster and are further from and have fewer links to other nodes. This again 
indicates that sustainability aspects are rarely mentioned together with product design terms in publications.

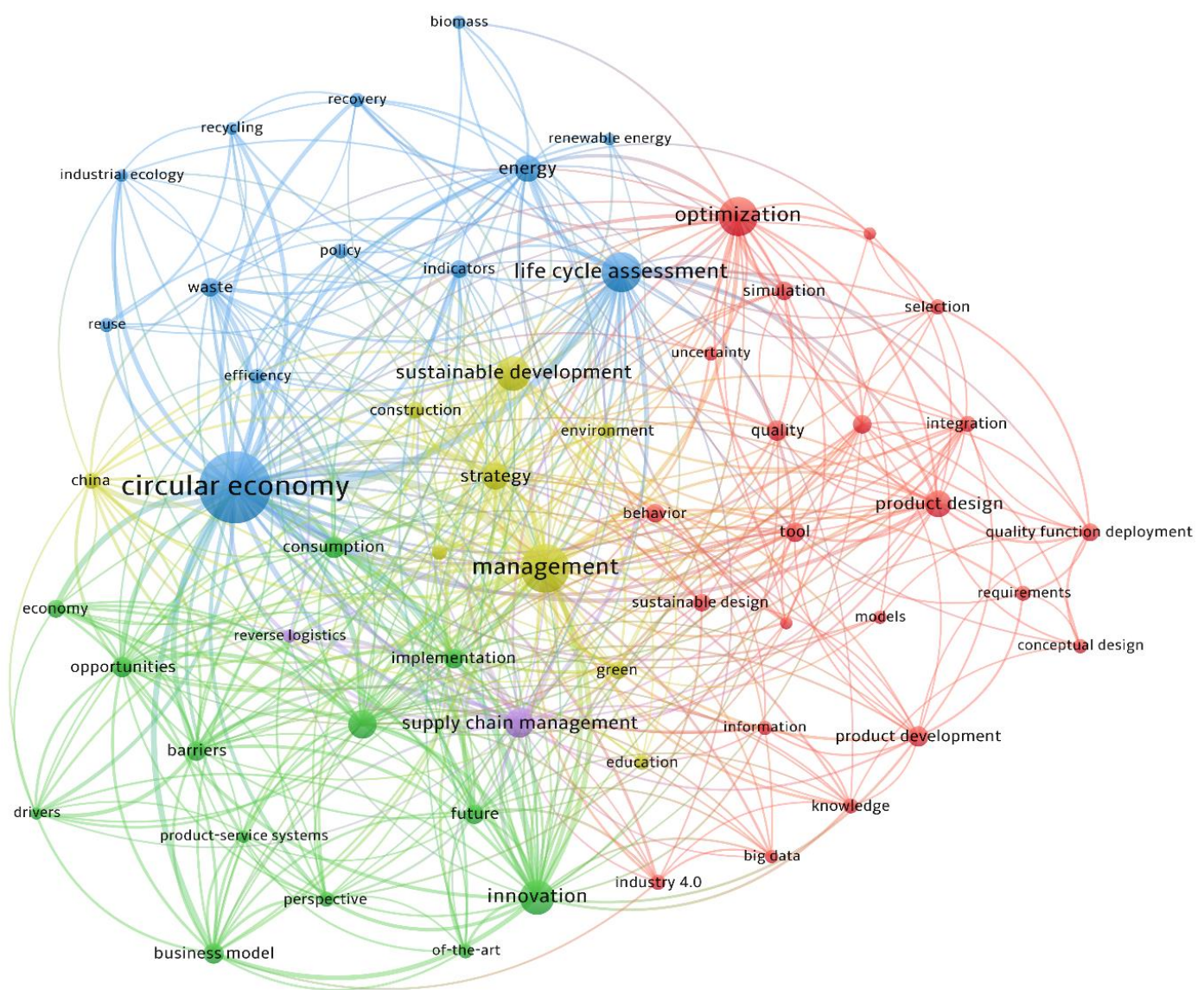

Figure 5. Network map of co-occurrence analysis of author keywords with 50 occurrences or more.

\section{Discussion and Future Directions}

In the review of contemporary sustainable product design research, two series of bibliometric and author keywords analysis were carried out in this article using "sustainable product design" and five separate searches, combining generic design phases and derived key words. Results from both analyses suggest that popular trends in recent research in sustainable product design include circular economy, life cycle assessment, sustainability development and management, and product optimization. Product design aspects are considered by the researchers, but they are failing to make their work searchable due to the keywords used in sustainability research, which so not correspond with what designers would look for. In other words, designers lack access to relevant sustainability research to make products more sustainable. This leads to the problem that the design process proceeds with a divorce process between design intent and design reality. For example, sustainability consideration and evaluation are often conducted separately as a life cycle assessment (LCA) at the end of the product development process. This may not be the intent of proponents of LCA studies and the circular economy but can nevertheless occur as a result of practitioners failing to notice a study or not following the defined strictures associated with a methodology. As mentioned earlier, decisions made at design stages have a significant impact on sustainability later. This raises the question of how sustainability can be emphasized throughout the design process. There is research that correlates sustainability with one or more product design phases, which is summarized by the skewed $\mathrm{V}$ diagram. Table 5 presents a list of example articles from the retrieved results, with limitations and future directions indicated. Based on the findings, the authors 
summarize four future directions of sustainability research in the context of product design, as shown in Figure 6.

Table 5. Examples of publications that consider sustainability in design phases.

\begin{tabular}{|c|c|c|}
\hline Design Phase & Publication & Limitation/Future Directions \\
\hline $\begin{array}{l}\text { Opportunity/ } \\
\text { Need analysis }\end{array}$ & $\begin{array}{l}\text { Ahmad et al. [6]; } \\
\text { Mesa et al. [45]; } \\
\text { Faludi et al. [46]; } \\
\text { Horani et al. [47]; } \\
\text { Liu et al. [48]; } \\
\text { Enyoghasi et al. [49] }\end{array}$ & $\begin{array}{l}\text { Most sustainable product design tools are used at late } \\
\text { design stages; Sustainable design recommendations } \\
\text { need to be made widely accessible and easy to } \\
\text { understand; Sustainability is often applied to single } \\
\text { products and difficult to adapted to personalized, } \\
\text { customizable products; Difficulty in identifying } \\
\text { opportunities for better sustainability considerations; } \\
\text { Price reductions for sustainable designs. }\end{array}$ \\
\hline Requirement analysis & $\begin{array}{l}\text { Haid and Albrecht [50]; } \\
\text { Miranda et al. [51]; } \\
\text { Watz et al. [52]; } \\
\text { Liu et al. [48]; }\end{array}$ & $\begin{array}{l}\text { Various definitions of sustainability in different } \\
\text { applications; Development of intelligent methods to } \\
\text { classify requirements. } \\
\text { Lack of traceability of sustainability requirements and } \\
\text { their validation; The need for systematic } \\
\text { requirement management. }\end{array}$ \\
\hline Specification & $\begin{array}{l}\text { Kuo \& Wang [53]; } \\
\text { Wang et al. [54]; } \\
\text { Su et al. [55]; } \\
\text { Mehdi and Boudi [56]; }\end{array}$ & $\begin{array}{l}\text { Validation of improved, more sustainable design } \\
\text { against specification; Some eco-features in specification } \\
\text { cannot be assigned with numerical values hence } \\
\text { cannot be easily assessed; Checklist for sustainable } \\
\text { product design can be used to improve specification. }\end{array}$ \\
\hline Concept design & $\begin{array}{l}\text { Lumsakul et al. [57]; } \\
\text { Han et al. [9]; } \\
\text { Wang et al. [54]; } \\
\text { Cheaitou et al. [58]; } \\
\text { Mehdi and Boudi [56]; }\end{array}$ & $\begin{array}{l}\text { Development of toolkit to improve collaboration } \\
\text { between design teams; Easy to use toolkits and better } \\
\text { ways to handle data; Experiences required to make } \\
\text { sensible decisions at the concept design stage; Idea } \\
\text { generation to green design is needed. }\end{array}$ \\
\hline $\begin{array}{l}\text { Component and } \\
\text { system design }\end{array}$ & $\begin{array}{l}\text { Zhang et al. [8]; } \\
\text { Hapuwatte and } \\
\text { Jawahir [7]; } \\
\text { Wang et al. [59]; } \\
\text { Ko [60]; } \\
\text { Romli et al. [61]; }\end{array}$ & $\begin{array}{l}\text { Consideration of uncertainties in decision making. } \\
\text { Social sustainability improvement is need for the } \\
\text { development of product-service systems; Limitation of } \\
\text { existing tools, e.g., case-based reasoning tool for new } \\
\text { design problems. }\end{array}$ \\
\hline
\end{tabular}

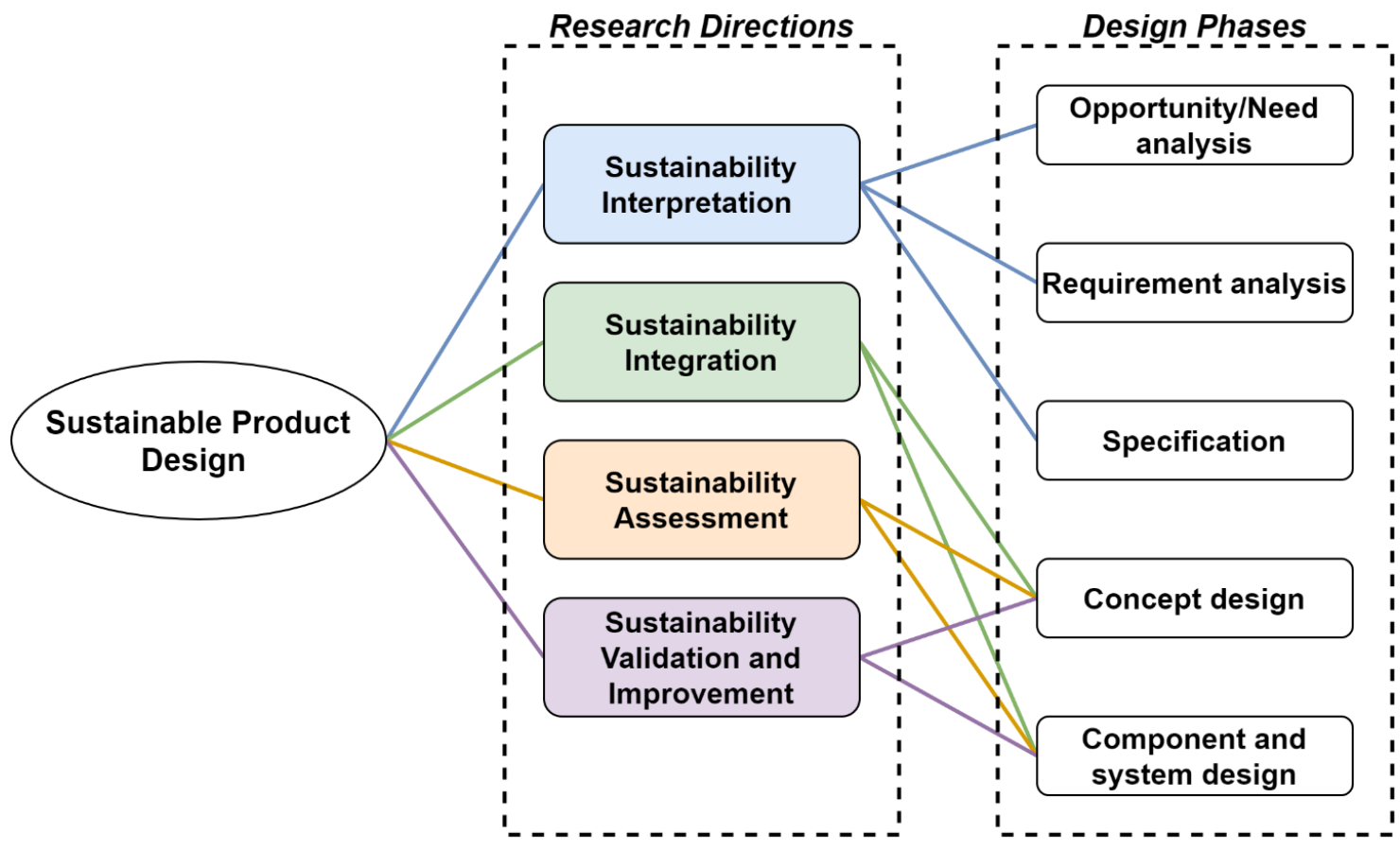

Figure 6. Future research directions in sustainable product design and their correlation with design phases. 


\subsection{Sustainability Interpretation}

This section describes how sustainability is defined across different sectors. For example, sustainability can have distinct meanings alongside a range of domains, from ontology of nature to the role of technology [62]. Even for product design, sustainability needs to be considered across its three standard dimensions: social, economic, and environmental, as well as different product categories. Ma and Kremer [63] merged the interpretation of sustainability from these three dimensions and the product life cycle, providing a guideline for designers as to what needs to be considered when designing a product, for example, material process, energy used, and recycle cost. Fernandes et al. [64] classified products into four categories and, for each category, defined the most important sustainability issues. The interpretation of sustainability will have a direct impact at the beginning of product design, where opportunities or needs can be identified by start taking sustainability into consideration. Requirement analysis and specification will also be affected by sustainability interpretation, in which what is needed for a product is defined qualitatively and then quantitatively.

\subsection{Sustainability Integration}

This section considers how the defined sustainability criteria can be integrated into product design. This can start occurring in the concept design phase, where principal solutions will be carried out, and later in the component and system design, where detailed selections of material, tolerances, and manufacturing attributes are determined. In addition to the product categorization, Fernandes et al. [64] also proposed strategies to integrate sustainability for different product categories, e.g., resource minimization and end-oflife planning. Similarly, Clark et al. [33] categorized the design for sustainability into redesign and new product design, suggesting incremental and racial changes, respectively. Sustainability integration aligns with the "operational level" of design for sustainability by Rocha et al. [65], in which sustainability considerations are addressed. A case study conducted by Sumter et al. [66] suggests that designers should apply an integrated systematic approach to incorporate circular business models and product design concurrently.

\subsection{Sustainability Assessment}

Sustainability assessment in product development concerns measures to support decision-making. This is closely related to concept design and component and system design, in which product concepts and embodiments need to be evaluated using the interpreted sustainability criteria for informed decision making. As mentioned earlier and further supported by Jawahir et al. [67], sustainability associated with product design is largely intuitive and difficult to quantify, hence more scientific methods of sustainability evaluation are needed. Isaksson et al. proposed a model-driven framework, combining both qualitative and quantitative methods to support early-stage design stages [68]. Han et al. [9] address this issue by applying four metrics for measuring product sustainability in the concept design phase, with respect to material, production, use, and end of life. The component and system design phase also require rational decisions being made, especially in the premanufacturing stage $[69,70]$.

\subsection{Sustainability Validation and Improvement}

This research direction describes how the outcome of a product design that went through all the aforementioned stages should be validated. This is closely related to sustainability interpretation as validations can become more effective if quantitative measures are used. Based on the validation, need, or opportunities for further improvement identified, the first stage of product design can be altered. However, the majority of the validation of product sustainability is covered in life cycle assessment, which is often carried out separately from product design. As a result, a closer association between product design and sustainability validation are desired to provide designers with a better approach to continuing performing design improvement, with respect to sustainability. 


\subsection{Implications and Limitations}

For academics, this review work first raises the awareness of missing links between research in sustainability and product design, implying that researchers fail to consider the impact of a design on sustainability throughout the design process. It uses the blended design process (i.e., the skewed V-diagram) to describe product development phases and correlates them with the four sustainable product design research directions proposed. This provides a guideline for academic researchers when conducting sustainability research in the context of product design. They will be able to go beyond tool-based approaches, e.g., LCA, to consider sustainability from an integrated point of view concerning product design processes.

For industries, this review article reveals that, due to the lack of access to relevant sustainability research regarding product design, the world continues to produce unsustainable products and processes. The four research directions proposed can also provide industries with a basis for integrating sustainability into their design processes. This will gradually improve the awareness of sustainability amongst designers, helping them to identify more relevant research and eventually start to produce sustainable products and processes.

One limitation of this research is that the database was constructed based on purely academic sources, without considering state-of-the-art practice in industries. There are several industrial interest groups addressing the need for sustainable design practices. Furthermore, companies are starting to implement Corporate Sustainability into their strategic vision; therefore, it is likely that sustainable product design will increasingly move onto the research agenda of companies. In many cases, the results of corporate $\mathrm{R} \& \mathrm{D}$ are not published to maintain a competitive edge. Therefore, any results of such industrial research activity was not included in this research. Secondly, not all academic knowledge is published, and thereby it is challenging to provide a fully comprehensive and up-to-theminute review regarding research in sustainable product design. Thirdly, the selection and systematization of the keywords are subject to the researchers' own judgments regarding the designated product development phases, theme clusters, and future directions.

\section{Conclusions}

Ecological and sustainable considerations pervade many aspects of product design. However, the authors believe, based on the analysis presented, that research studies commonly fail to establish links between sustainability research and activities carried out during product design, which leads to a divorced process between design intent and design reality. This can further lead to a lack of access to relevant sustainability research to make products more sustainable. To demonstrate this, a series of bibliometric analysis was carried out for publications related to sustainable product design within the past three years using Web of Science. Both article subject areas and the journals in which articles were published show that sustainability in product design has been overlooked. It is indicated that, for both analyses, more than $59 \%$ of the publications focus on these three subject areas: green sustainable science technology, environmental sciences, and engineering environmental. Journals that the articles published in are mainly Sustainability (23\% and $45 \%$ for the two analyses) and the Journal of Cleaner Production (22\% and $33 \%$ for the two analyses). The two network maps produced using VOSViewer as part of the consideration of the literature relevant to this topic have revealed six and five extensive research focuses, respectively, including the concentration of attention on management, optimization, life cycle assessment, and circular economy. The network maps also illustrate the attention to specific materials, material flows, environmental impact, and consumer behaviors. However, only some product design-related terms, with very few co-occurrences with other keywords, were identified from network maps, which is in line with the findings of the preceding analysis on subject areas and journals. Drawn from the analysis, the authors propose four future research directions that are closely correlated 
with product design phases that aim to provide a signpost for researchers when conducting sustainable product design.

Author Contributions: Conceptualization, P.J., E.D., J.H. and P.R.N.C.; methodology, P.J., E.D. and J.H.; software, P.J.; investigation, P.J. and E.D.; formal analysis, P.J.; supervision, P.R.N.C.; writing—original draft preparation, P.J., E.D., J.H. and P.R.N.C.; writing—review and editing, P.J., E.D., J.H. and P.R.N.C. All authors have read and agreed to the published version of the manuscript.

Funding: This research received no external funding.

Institutional Review Board Statement: Not applicable.

Informed Consent Statement: Not applicable.

Data Availability Statement: Publicly available datasets were analyzed in this study. This data can be found here: https:/ / kingston.box.com/s / 0ywd3rzw80cktpytwztvbvkm48urh2qq (accessed on 19 October 2021).

Conflicts of Interest: The authors declare no conflict of interest.

\section{References}

1. Papanek, V. Design for the Real World: Human Ecology and Social Change, 2nd ed.; Academy Chicago Publishers: Chicago, IL, USA, 1985.

2. De Wit, M.; Hoogzaad, J.; von Daniels, C. The Circularity Gap Report; Circle Economy: Amsterdam, The Netherlands, 2020.

3. Hallstedt, S.I.; Isaksson, O. Material Criticality Assessment in Early Phases of Sustainable Product Development. J. Clean. Prod. 2017, 161, 40-52. [CrossRef]

4. Aydin, R.; Badurdeen, F. Sustainable Product Line Design Considering a Multi-Lifecycle Approach. Resour. Conserv. Recycl. 2019, 149, 727-737. [CrossRef]

5. Braungart, M.; McDonough, W. Cradle to Cradle. Remaking the Way We Make Things, 1st ed.; Vintage: New York, NY, USA, 2009.

6. Ahmad, S.; Wong, K.Y.; Tseng, M.L.; Wong, W.P. Sustainable Product Design and Development: A Review of Tools, Applications and Research Prospects. Resour. Conserv. Recycl. 2018, 132, 49-61. [CrossRef]

7. Hapuwatte, B.M.; Jawahir, I.S. Closed-Loop Sustainable Product Design for Circular Economy. J. Ind. Ecol. 2021, 1-17. [CrossRef]

8. Zhang, X.; Zhang, L.; Fung, K.Y.; Bakshi, B.R.; Ng, K.M. Sustainable Product Design: A Life-Cycle Approach. Chem. Eng. Sci. 2020, 217, 115508. [CrossRef]

9. Han, J.; Jiang, P.; Childs, P.R.N. Metrics for Measuring Sustainable Product Design Concepts. Energies 2021, 14, 3469. [CrossRef]

10. Rodrigues, V.P.; Pigosso, D.C.A.; McAloone, T.C. Process-Related Key Performance Indicators for Measuring Sustainability Performance of Ecodesign Implementation into Product Development. J. Clean. Prod. 2016, 139, 416-428. [CrossRef]

11. Ceschin, F.; Gaziulusoy, I. Evolution of Design for Sustainability: From Product Design to Design for System Innovations and Transitions. Des. Stud. 2016, 47, 118-163. [CrossRef]

12. Mestre, A.; Vogtlander, J. Eco-Efficient Value Creation of Cork Products: An LCA-Based Method for Design Intervention. J. Clean. Prod. 2013, 57, 101-114. [CrossRef]

13. Deng, C.; Wu, J.; Shao, X. Research on Eco-Balance with LCA and LCC for Mechanical Product Design. Int. J. Adv. Manuf. Technol. 2016, 87, 1217-1228. [CrossRef]

14. Civancik-Uslu, D.; Puig, R.; Voigt, S.; Walter, D.; Fullana-i-Palmer, P. Improving the Production Chain with LCA and Eco-Design: Application to Cosmetic Packaging. Resour. Conserv. Recycl. 2019, 151, 104475. [CrossRef]

15. Bereketli, I.; Erol Genevois, M. An Integrated QFDE Approach for Identifying Improvement Strategies in Sustainable Product Development. J. Clean. Prod. 2013, 54, 188-198. [CrossRef]

16. Wu, Y.H.; Ho, C.C. Integration of Green Quality Function Deployment and Fuzzy Theory: A Case Study on Green Mobile Phone Design. J. Clean. Prod. 2015, 108, 271-280. [CrossRef]

17. Younesi, M.; Roghanian, E. A Framework for Sustainable Product Design: A Hybrid Fuzzy Approach Based on Quality Function Deployment for Environment. J. Clean. Prod. 2015, 108, 385-394. [CrossRef]

18. Hansen, J.W.; Jones, J.W. A Systems Framework for Characterizing Farm Sustainability. Agric. Syst. 1996, 51, 185-201. [CrossRef]

19. Hueting, R.; Reijnders, L. Sustainability Is an Objective Concept. Ecol. Econ. 1998, 27, 3-8.

20. Ehrenfeld, J.R. Searching for Sustainability. Reflections 2004, 5, 1-13.

21. Figge, C. Sustainability: Defining the Undefinable. Available online: https://www.triplepundit.com/story/2011/sustainabilitydefining-undefinable/78476 (accessed on 15 September 2021).

22. Ott, H.; Wang, R.; Bortree, D. Communicating Sustainability Online: An Examination of Corporate, Nonprofit, and University Websites. Mass Commun. Soc. 2016, 19, 671-687. [CrossRef]

23. World Commission on Environment and Development. Our Common Future; Oxford University Press: Oxford, UK, 1987.

24. Purvis, B.; Mao, Y.; Robinson, D. Three Pillars of Sustainability: In Search of Conceptual Origins. Sustain. Sci. 2019, 14, 681-695. [CrossRef] 
25. Hansmann, R.; Mieg, H.A.; Frischknecht, P. Principal Sustainability Components: Empirical Analysis of Synergies between the Three Pillars of Sustainability. Int. J. Sustain. Dev. World Ecol. 2012, 19, 451-459. [CrossRef]

26. Littig, B.; Grießler, E. Social Sustainability: A Catchword between Political Pragmatism and Social Theory. Int. J. Sustain. Dev. 2005, 8, 65-79. [CrossRef]

27. Miller, E. Economization and Beyond: (Re)Composing Livelihoods in Maine, USA. Environ. Plan. A Econ. Space 2014, 46, $2735-2751$. [CrossRef]

28. Eslami, Y.; Dassisti, M.; Lezoche, M.; Panetto, H. A Survey on Sustainability in Manufacturing Organisations: Dimensions and Future Insights. Int. J. Prod. Res. 2019, 57, 5194-5214. [CrossRef]

29. Orenstein, D.E.; Shach-Pinsley, D. A Comparative Framework for Assessing Sustainability Initiatives at the Regional Scale. World Dev. 2017, 98, 245-256. [CrossRef]

30. Pugh, S. Total Design: Integrated Methods for Successful Product Engineering; Addison-Wesley Publishing Company: Boston, MA, USA, 1991.

31. Birch, A.; Hon, K.K.B.; Short, T. Structure and Output Mechanisms in Design for Environment (DfE) Tools. J. Clean. Prod. 2012, 35, 50-58. [CrossRef]

32. Ramani, K.; Ramanujan, D.; Bernstein, W.Z.; Zhao, F.; Sutherland, J.; Handwerker, C.; Choi, J.K.; Kim, H.; Thurston, D. Integrated Sustainable Life Cycle Design: A Review. J. Mech. Des. Trans. ASME 2010, 132, 091004. [CrossRef]

33. Clark, G.; Kosoris, J.; Hong, L.N.; Crul, M. Design for Sustainability: Current Trends in Sustainable Product Design and Development. Sustainability 2009, 1, 409-424. [CrossRef]

34. Fargnoli, M.; De Minicis, M.; Tronci, M. Design Management for Sustainability: An Integrated Approach for the Development of Sustainable Products. J. Eng. Technol. Manag. 2014, 34, 29-45. [CrossRef]

35. He, B.; Gu, Z. Sustainable Design Synthesis for Product Environmental Footprints. Des. Stud. 2016, 45, 159-186. [CrossRef]

36. Childs, P.R.N. Mechanical Design Theory and Applications, 3rd ed.; Elsevier Science: Amsterdam, The Netherlands, 2021.

37. Bröhl, A.P.; Dröschel, W. Das V-Modell: Der Standard Für Die Softwareentwicklung Mit Praxisleitfaden, 2nd ed.; Oldenbourg Wissenschaftsverlag: Munich, Germany, 1995.

38. Dash, M. Three Pillars of a Biomedical Research Article: The Title, Abstract and Keywords. J. Health Spec. 2016, 4, 186. [CrossRef]

39. WOS. Web of Science Core Collection: Search Tips. Available online: https://clarivate.libguides.com/woscc/searchtips (accessed on 15 September 2021).

40. Springer. Title, Abstract and Keywords. Available online: https://www.springer.com/gp/authors-editors/authorandreviewertutorials/ writing-a-journal-manuscript/title-abstract-and-keywords/10285522 (accessed on 15 September 2021).

41. Aghaei Chadegani, A.; Salehi, H.; Yunus, M.M.; Farhadi, H.; Fooladi, M.; Farhadi, M.; Ale Ebrahim, N. A Comparison between Two Main Academic Literature Collections: Web of Science and Scopus Databases. Asian Soc. Sci. 2013, 9, 18-26. [CrossRef]

42. WOS. Web of Science Core Collection: Data Mining Using "Analyze Results". Available online: https://clarivate.libguides.com/ woscc/analyze (accessed on 15 September 2021).

43. Lewis, H.; Gertsakis, J.; Grant, T.; Morelli, N.; Sweatman, A. Design + Environment, 1st ed.; Routledge: Abingdon, UK, 2001.

44. Van Eck, N.J.; Waltman, L. VOSviewer Manual; Universiteit Leiden: Leiden, The Netherlands, 2021; pp. 1-54.

45. Mesa, J.A.; Esparragoza, I.; Maury, H. Trends and Perspectives of Sustainable Product Design for Open Architecture Products: Facing the Circular Economy Model. Int. J. Precis. Eng. Manuf. Technol. 2019, 6, 377-391. [CrossRef]

46. Faludi, J.; Hoffenson, S.; Kwok, S.Y.; Saidani, M.; Hallstedt, S.I.; Telenko, C.; Martinez, V. A Research Roadmap for Sustainable Design Methods and Tools. Sustainability 2020, 12, 8174. [CrossRef]

47. Horani, L.F. A Systematic Literature Review on Changing Customer Requirements for Sustainable Design over Time. Int. J. Econ. Manag. Eng. 2017, 11, 956-968. [CrossRef]

48. Liu, C.; Jia, G.; Kong, J. Requirement-Oriented Engineering Characteristic Identification for a Sustainable Product-Service System: A Multi-Method Approach. Sustainability 2020, 12, 8880. [CrossRef]

49. Enyoghasi, C.; Badurdeen, F. Industry 4.0 for Sustainable Manufacturing: Opportunities at the Product, Process, and System Levels. Resour. Conserv. Recycl. 2021, 166, 105362. [CrossRef]

50. Haid, M.; Albrecht, J.N. Sustainable Tourism Product Development: An Application of Product Design Concepts. Sustainability 2021, 13, 7957. [CrossRef]

51. Miranda, J.; Ponce, P.; Molina, J.M.; Molina, A. Taxonomy of Levels of Sensing, Smart and Sustainable Products to Support New Product Development. IFAC PapersOnLine 2019, 52, 2384-2389. [CrossRef]

52. Watz, M.; Hallstedt, S.I. Profile Model for Management of Sustainability Integration in Engineering Design Requirements. J. Clean. Prod. 2020, 247, 119155. [CrossRef]

53. Kuo, T.C.; Wang, C.-J. Integrating Robust Design Criteria and Axiomatic Design Principles to Support Sustainable Product Development. Int. J. Precis. Eng. Manuf. Technol. 2019, 6, 549-557. [CrossRef]

54. Wang, S.; Su, D.; Ma, M.; Kuang, W. Sustainable Product Development and Service Approach for Application in Industrial Lighting Products. Sustain. Prod. Consum. 2021, 27, 1808-1821. [CrossRef]

55. Su, D.; Casamayor, J.L.; Xu, X. An Integrated Approach for Eco-Design and Its Application in Led Lighting Product Development. Sustainability 2021, 13, 488. [CrossRef]

56. Mehdi, I.; Boudi, E.M. Towards a Sustainable Conceptual Design of Mechatronic Systems Application to a Regenerative Braking System. Mater. Today Proc. 2021, 45, 7588-7596. [CrossRef] 
57. Lumsakul, P.; Sheldrick, L.; Rahimifard, S. The Sustainable Co-Design of Products and Production Systems. Proc. Manuf. 2018, 21, 854-861. [CrossRef]

58. Cheaitou, A.; Gardoni, M.; Hamdan, S. A Decision-Making Framework for Environmentally Sustainable Product Design. Concurr. Eng. 2019, 27, 295-304. [CrossRef]

59. Wang, S.; Su, D.; Wu, Y.; Chai, Z. Application of Life-Cycle Assessment to the Eco-Design of LED Lighting Products. Euro-Mediterr. J. Environ. Integr. 2020, 5, 41. [CrossRef]

60. Ko, Y.T. Modeling an Innovative Green Design Method for Sustainable Products. Sustainability 2020, 12, 3351. [CrossRef]

61. Romli, A.; Setchi, R.; Prickett, P.; De la Pisa, M. Eco-Design Case-Based Reasoning Tool: The Integration of Ecological Quality Function Deployment and Case-Based Reasoning Methods for Supporting Sustainable Product Design. Proc. Inst. Mech. Eng. Part B J. Eng. Manuf. 2018, 232, 1778-1797. [CrossRef]

62. Vos, R.O. Defining Sustainability: A Conceptual Orientation. J. Chem. Technol. Biotechnol. 2007, 82, 334-339. [CrossRef]

63. Ma, J.; Kremer, G.E.O. A Systematic Literature Review of Modular Product Design (MPD) from the Perspective of Sustainability. Int. J. Adv. Manuf.Technol. 2016, 86, 1509-1539. [CrossRef]

64. Fernandes, P.T.; Canciglieri Júnior, O.; Sant'Anna, Â.M.O. Method for Integrated Product Development Oriented to Sustainability. Clean Technol. Environ. Policy 2017, 19, 775-793. [CrossRef]

65. Rocha, C.S.; Antunes, P.; Partidário, P. Design for Sustainability Models: A Multiperspective Review. J. Clean. Prod. 2019, $234,1428-1445$. [CrossRef]

66. Sumter, D.; Bakker, C.; Balkenende, R. The Role of Product Design in Creating Circular Business Models: A Case Study on the Lease and Refurbishment of Baby Strollers. Sustainability 2018, 10, 2415. [CrossRef]

67. Jawahir, I.S.; Wanigarathne, P.C.; Wang, X. Product Design and Manufacturing Process for Sustainability. In Mechanical Engineers' Handbook: Manufacturing and Management; Kutz, M., Ed.; John Wiley \& Sons, Inc.: Hoboken, NJ, USA, 2006.

68. Isaksson, O.; Bertoni, M.; Hallstedt, S.; Lavesson, N. Model Based Decision Support for Value and Sustainability in Product Development. In Proceedings of the International Conference on Engineering Design, Milan, Italy, 27-30 July 2015; pp. 1-11.

69. Jayal, A.D.; Badurdeen, F.; Dillon, O.W.; Jawahir, I.S. Sustainable Manufacturing: Modeling and Optimization Challenges at the Product, Process and System Levels. CIRP J. Manuf. Sci. Technol. 2010, 2, 144-152. [CrossRef]

70. Jawahir, I.S.; Dillon, O.W.; Rouch, K.E.; Joshi, K.J.; Jaafar, I.H. Total Life-Cycle Consideration in Product Design for Sustainability: A Framework for Comprehensive Evaluation. In Proceedings of the TMT 2006, Barcelona, Spain, 11-15 September 2006. 